\title{
Chemical Composition and Bioavailability of Zinc and Iron in Kunu-zaki, a Nigerian Traditional Beverage
}

\author{
Igwe, C.U. ${ }^{* a}$, Ibegbulem, C.O. ${ }^{b}$, Nwaogu, L.A. ${ }^{c}$, Ujowundu, C.O. ${ }^{d}$ \\ and Ene, A.C.
}

Department of Biochemistry, Federal University of Technology, Owerri, Nigeria

${ }^{* a}$ Corresponding author: Email address: igwechidi9@gmail.com

Phone No.: +234 (0) 8066075587

bibemog@yahoo.com; 'nwogulinus@gmail.com; dujowundu@yahoo.com; ${ }^{d}$ chineduene@gmail.com

Keywords: Germination, fermentation, mineral bioavailability, sorghum.

\begin{abstract}
The effect of processing (germination and fermentation) on the chemical composition (proximate, mineral and phytochemical contents) of a Nigerian traditional beverage, kunu-zaki made from sorghum (Sorghum bicolor) grains with the addition of sweet potato (Ipomonea batatas) paste were studied. The bioavailability of $\mathrm{Zn}$ and $\mathrm{Fe}$ in the beverage were also assessed using phytate, $\mathrm{Zn}, \mathrm{Ca}$ and $\mathrm{Fe}$ molar ratios. Processing of sorghum into kunu-zaki significantly $(\mathrm{p}<0.05)$ increased its ash (26.32\%), $\mathrm{Na}(21.28 \%), \mathrm{Ca}(20.59 \%), \mathrm{Fe}(21.62 \%), \mathrm{Zn}(13.43 \%)$, flavonoids $(11.11 \%)$ and alkaloids $(30.00 \%)$ contents, but decreased its protein $(-43.75 \%)$, fiber $(-28.57 \%)$, phenols $(-43.80 \%)$, saponin $(-62.67 \%)$, tannin $(-43.80 \%)$, oxalate $(-33.33 \%)$ and phytate $(-60.27 \%)$ contents. Addition of sweet potato paste to kunu-zaki apparently aided in enhancing its chemical composition. The combination of germination and fermentation as processing techniques were better than germination alone in significantly $(\mathrm{p}<0.05)$ improving the bioavailability of Fe and $\mathrm{Zn}$, and reducing the anti-nutrient content of kunu-zaki, in comparison with both raw and germinated sorghum grains. In conclusion, the kunu-zaki had low contents of protein and fiber, adequate arrays of other functional nutrients and potentially high bioavailability of $\mathrm{Fe}$ and $\mathrm{Zn}$.
\end{abstract}

\subsection{Introduction}

Kunu-zaki is an African traditional non-alcoholic beverage that has been popular in Nigeria for decades. It is produced by traditional fermentation of cereal grains by beneficial microbes, and has been widely known for its high acceptability, palatability and energy replenishing potentials, which is claimed to be related to its rich content of various functional components. Kunu-zaki, a product of lactic acid fermentation [1], is commonly prepared locally by women, and taken mainly by low and middle income earners for its thirst quenching and energy-giving properties. It is also used locally for entertainment at homes and during festivities such as Sallah and Christmas ceremonies [2]. Depending on the major cereal used in kunu-zaki production, the common types of the beverage include kunun zaki, kunun gyada, kunun akamu, kunun tsamiya and kunun baule [3]. Although, cereals can be used in composite form in the production of kunu-zaki, sorghum (Sorghum bicolor) and millet (Pennisetum americanum) grains are the most commonly used raw materials [2]. However, maize (Zea mays), rice, acha (Digitaria exilis), guinea corn and other grains may also be used [1].

The traditional production process involves steeping of the chosen cereal or mixture of the cereals in water for $24-72$ hours and wet milling with the aid of a local grinding machine. The steeped and washed grains are usually ground with species such as ginger, clove, red and/or black pepper depending on the taste of the local producer. The slurry obtained is sieved and divided into two unequal portions. A potion (two-third volume) of the slurry is gelatinized with boiling hot water, while to the remaining portion (one-third volume), about an equal volume of sweet potato (Ipomonea batatas) tuber paste, malted rice paste or extract of Cadaba farinose stem is added and mixed. The latter mixture is mixed vigorously and thoroughly with the former, the gelatinized portion while still hot, and allowed to ferment for 24 hours at room temperature. After which, it is 
filtered using a local sieve and the filtrate, kunu-zaki, is consumed as a beverage with or without the addition of a sweetener, usually sugar. The beverage can be consumed fresh or bottled and stored at refrigeration temperature $[2,4,5]$.

Cereal grains and their different products form the major source of dietary nutrients for many people, especially those in the developing countries of the world. However, it has been reported that the nutritional quality of cereal grains and their products are inferior due to lower protein content, deficiency of certain essential amino acids, lower protein and starch availabilities, presence of certain anti-nutrients and the coarse nature of the grains [6]. In line with the above report, kunu-zaki has been noted to have a gross chemical composition of $87.85-89 \%$ moisture, $9.84-12 \%$ carbohydrate, $1.56-3 \%$ protein, $0.10-0.30 \%$ fat and $0.61-0.75 \%$ ash, indicating that the drink is low in protein [2]. Furthermore, like other cereal based products, kunu-zaki may contain high amounts of anti-nutrient that may affect nutrient availability. Anti-nutrients found in cereals, such as phytate, can decrease the absorption of minerals such as $\mathrm{Zn}, \mathrm{Ca}, \mathrm{Fe}$ and $\mathrm{Mn}$, and high intake of these anti-nutrients might lead to mineral deficiency. Zinc and iron are essential trace elements in human nutrition, whose deficiencies are among the common nutritional problems affecting the world. Their deficiencies are of major concern because of the serious health consequences they have, as well as the large number of people afflicted; especially in developing countries of the world. These deficiencies may be caused by the presence of certain anti-nutrients, especially the ability of phytate to reduce dietary $\mathrm{Zn}$ and Fe bioavailability by formation of insoluble mineral chelates at physiological $\mathrm{pH}$. The formation and stability of these chelates depend on the relative concentrations of $\mathrm{Zn}, \mathrm{Fe}$ and phytate as well as on the levels of dietary Ca present $[7,8]$. However, certain traditional food processing techniques, either individually or in combination, such as germination, steeping, fermentation, and boiling of grains for a limited period have been reported to cause increased activities of hydrolytic enzymes, improvement in the contents of certain essential amino acids, total sugars, B-group vitamins, and a decrease in dry matter, starch and anti-nutrients [9]. Thus, the present study is aimed at determining the effect of fermentation and germination, and the addition of sweet potato tuber paste on the chemical composition and bioavailability of $\mathrm{Zn}$ and Fe in kunu-zaki drink.

\subsection{Materials and Methods}

\subsection{Collection of materials}

The sorghum (Sorghum bicolor) grains and fresh sweet potato (Ipomonea batatas) tubers were purchased from Mami-Market, Obinze in Owerri-West Local Government Area of Imo State, and authenticated at the Department of Crop Science, Federal University of Technology, Owerri, Nigeria.

\subsection{Laboratory Production of Kunu-zaki}

The Kunu-zaki was produced by a modified method (Figure 1), based on the traditional method of production as described by [2,5]. In brief, $500 \mathrm{~g}$ of apparently healthy sorghum grains were washed and steeped in $1000 \mathrm{ml}$ of water for 24 hours at room temperature $\left(30^{\circ} \mathrm{C}\right)$. The steeped grains were drained of water, covered with moist paper-bag for 72 hours at room temperature for germination. Visible root portions of germinated grains were manually removed. After which, they were wet milled using Kenwood major blender (Model Titanium KM020, Kenwood Chef Major, Giovanni, UK) and sieved with a muslin cloth to obtain a slurry. The paste was then divided into two unequal (two-third and one-third) portions. To the larger portion, 3 liters of boiling hot water was added and turned vigorously until a gelatinized paste was obtained. To the smaller portion, $10 \mathrm{~g}$ of washed and ground fresh sweet potato paste was added. The gelatinized sample was allowed to cool to about $50^{\circ} \mathrm{C}$, and the later mixture was added to it and stirred vigorously but thoroughly for about $5 \mathrm{~min}$. The combined mixture was covered with paper-bag, allowed to ferment for 12 hours and then filtered with the aid of a cloth sieve to obtain an un-sweetened kunu-zaki. 
Sorghum grains

Wash and steep in water for 12 hours at $30^{\circ} \mathrm{C}$.

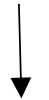

Drain and cover to germinate for 72 hours at $30^{\circ} \mathrm{C}$.

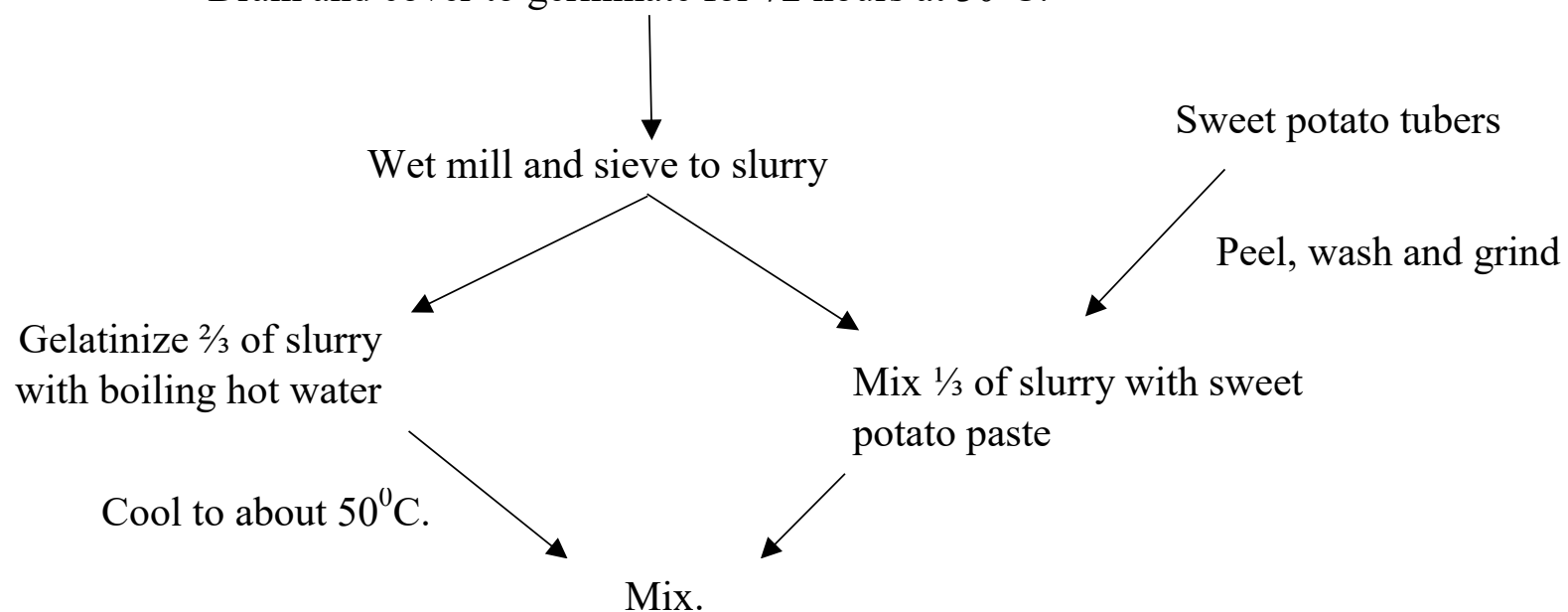

Ferment for 12 hours at $30^{\circ} \mathrm{C}$ and sieve

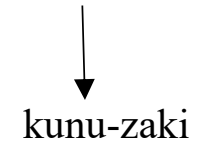

Figure 1: Flow chart for laboratory production of kunu-zaki

\subsection{Chemical Analyses}

For all chemical analyses, four different samples were collected during the course of production of the kunu-zaki:

i. Ground but unfermented sorghum paste (raw sorghum sample)

ii. Ground 72 hour germinated sorghum paste (germinated sorghum sample)

iii. Ground fresh sweet potato paste (Raw potato sample)

iv. Complete, ready-to-drink un-sweetened kunu-zaki (kunu-zaki sample)

\subsubsection{Proximate analyses}

Crude fat was extracted by the soxhlet method with petroleum ether $\left(40-60^{\circ} \mathrm{C}\right)$ for 8 hours and then determined along with moisture, total ash and crude fibre of the samples by the methods of [10]. Nitrogen was determined by the micro-Kjeldahl method and the crude protein content was calculated as $\mathrm{N} \times$ 6.25. Carbohydrate was determined by difference. The energy values were calculated using the Atwater system as described by [11]. All the proximate results were reported as $\mathrm{g} / 100 \mathrm{~g}$ dry weight and based on triplicate determinations.

\subsubsection{Mineral Analyses}

A portion, $2.0 \mathrm{~g}$ of each sample was incinerated in a Carbolite furnace (Carbolite, Derbyshire, UK) at $600^{\circ} \mathrm{C}$ for 3 hours to constant weight. The ashed samples obtained were allowed to cool and each was transferred into a separate $50 \mathrm{ml}$ beaker, with the crucible washed with $25 \mathrm{ml}$ of $6 \mathrm{~N} \mathrm{HCl}$ into the corresponding beaker. The beaker was then heated to boiling to break the ash. The solution was carefully filtered and transferred into a $50 \mathrm{ml}$ standard flask and made up to the mark with distilleddeionized water. The resulting extract was used for the determination of sodium and potassium concentrations using a flame photometer (Model 405, Corning, Halstead Essex, UK), while 
calcium, magnesium, iron and zinc contents were determined by the use of an atomic absorption spectrophotometer (Alpha 4, Chem. Tech. Analytical, England). Phosphorous was determined as phosphate by the Vanadomolybdate colorimetric method [12]. All determinations were made in triplicates.

\subsubsection{Phytochemical Analyses}

The percentage compositions $(\mathrm{g} / 100 \mathrm{~g})$ of saponins, tannins, alkaloids, flavonoids, oxalate and cyanogenic glycosides were determined according to the methods described by $[13,14]$. The amount of total phenols in the samples were determined using the Folin-Ciocalteau method [15].

Phytate was extracted according to the procedure described by [16]. Briefly, $1.0 \mathrm{~g}$ of each sample was extracted with $3 \%$ trichloroacetic acid (TCA) at $37^{\circ} \mathrm{C}$ for $45 \mathrm{~min}$ with simple shaking followed by centrifugation and extraction using anion exchange column. The extracted solution $(0.2 \mathrm{ml})$ was mixed with $4.6 \mathrm{ml}$ of distilled water and $0.2 \mathrm{ml}$ of chromogenic solution and the tubes were heated in a water bath at $95^{\circ} \mathrm{C}$ for $30 \mathrm{~min}$, and allowed to cool. The developed colour was read at $830 \mathrm{~nm}$ against blank. Standard phytate solution was prepared by dissolving sodium phytate in distilled water to prepare different phytate concentrations, which were treated as described above for the tested samples. The amount of phytate in the tested samples was expressed as mg phytate/100 $\mathrm{g}$ sample. All determinations were made in triplicates.

\subsection{Calculated mineral and molar ratios}

$\mathrm{Ca} / \mathrm{P}, \mathrm{Na} / \mathrm{K}, \mathrm{Ca} / \mathrm{Mg}$ and the miliiequivalent ratio of $[\mathrm{K} /(\mathrm{Ca}+\mathrm{Mg})]$ were calculated as described by [17], while the molar ratios [Phy]:[Fe], [Phy]:[Zn], [Ca]:[Phy] and [Ca][Phy]:[Zn] were computed as described by [8].

\subsection{Statistical Analysis}

All determinations were carried out in triplicates and expressed as mean \pm standard deviations. Oneway analysis of variance (ANOVA) and post-hoc Tukey test were used to analyse data generated with the aid of GraphPad Prism version 5.3. Differences between means at $p \leq 0.05$ were considered statistically significant.

\subsection{Results and Discussion}

\subsection{Changes in proximate composition of germinated sorghum and kunu-zaki.}

Table 1 shows the proximate composition of the raw sorghum, raw potato, germinated sorghum and kunu-zaki beverage. Their carbohydrate content was generally high with values ranging from $65.10 \mathrm{~g} / 100 \mathrm{~g}$ (potato) to $69.02 \mathrm{~g} / 100 \mathrm{~g}$ (kunu-zaki), while the protein, lipid, ash and fiber contents were generally low. The energy values were high with a range of $1.67 \times 10^{4} \mathrm{~kJ} / \mathrm{kg}$ (germinated sorghum) to $1.78 \times 10^{4} \mathrm{~kJ} / \mathrm{kg}$ (potato). A further study of the Table 1 shows that addition of raw potato paste to the kunu-zaki did not significantly affect its proximate composition in comparison with the effect of the basic composite (raw sorghum), except for the energy values, where that of the raw potato was non-significantly $(\mathrm{p}>0.05)$ similar to that of kunu-zaki, but significantly $(p<0.05)$ higher than those of both germinated and raw sorghum. This observation could be directly attributed to the significantly $(\mathrm{p}<0.05)$ higher lipid content of potato than those of both the raw and germinated sorghum. 
Table 1: Proximate composition $(\mathrm{g} / 100 \mathrm{~g})$ of raw sorghum, raw potato, germinated sorghum and kunu-zaki.

\begin{tabular}{|l|l|l|l|l|}
\hline Proximate & Raw sorghum & Raw potato & $\begin{array}{l}\text { Germinated } \\
\text { sorghum }\end{array}$ & Kunu-zaki \\
\hline Carbohydrate & $68.46 \pm 1.38^{\mathrm{a}}$ & $65.10 \pm 2.01^{\mathrm{a}}$ & $68.10 \pm 1.23^{\mathrm{a}}$ & $69.02 \pm 2.00^{\mathrm{a}}$ \\
\hline Protein & $5.60 \pm 0.81^{\mathrm{a}}$ & $1.23 \pm 0.12^{\mathrm{b}}$ & $3.34 \pm 0.24^{\mathrm{c}}$ & $3.15 \pm 0.15^{\mathrm{c}}$ \\
\hline Lipid & $11.75 \pm 1.09^{\mathrm{a}}$ & $17.66 \pm 1.80^{\mathrm{b}}$ & $12.37 \pm 1.32^{\mathrm{a}}$ & $14.20 \pm 1.13^{\mathrm{ab}}$ \\
\hline Moisture & $8.27 \pm 0.97^{\mathrm{a}}$ & $10.09 \pm 1.03^{\mathrm{ab}}$ & $11.45 \pm 0.98^{\mathrm{b}}$ & $8.47 \pm 0.87^{\mathrm{a}}$ \\
\hline Ash & $1.71 \pm 0.33^{\mathrm{ab}}$ & $2.22 \pm 0.13^{\mathrm{a}}$ & $1.54 \pm 0.18^{\mathrm{b}}$ & $2.16 \pm 0.16^{\mathrm{a}}$ \\
\hline Fiber & $4.20 \pm 0.51^{\mathrm{a}}$ & $3.70 \pm 0.32^{\mathrm{ac}}$ & $3.20 \pm 0.27^{\mathrm{bc}}$ & $3.00 \pm 0.17^{\mathrm{bc}}$ \\
\hline Energy $\left(\mathrm{x} 10^{4} \mathrm{~kJ} / \mathrm{kg}\right)$ & $1.69 \pm 0.06^{\mathrm{ab}}$ & $1.78 \pm 0.02^{\mathrm{a}}$ & $1.67 \pm 0.03^{\mathrm{b}}$ & $1.75 \pm 0.01^{\mathrm{ab}}$ \\
\hline
\end{tabular}

Values are mean \pm standard deviations of triplicate determinations. Values with similar superscripts per row are not significantly $(\mathrm{p}<0.05)$ different.

From Figure 2, it could be seen that germination and fermentation as traditional methods of processing raw sorghum grains into kunu-zaki non-significantly $(\mathrm{p}>0.05)$ increased its carbohydrate content $(0.82 \%)$, but significantly $(\mathrm{p}<0.05)$ reduced its protein $(-43.75 \%)$ and fiber $(-28.57 \%)$ contents. Although, this is in agreement with earlier reports of low protein content $(1.56-3 \%)$ in kunu-zaki [2,18], but the low levels of fiber and protein observed could be deleterious, since proteins are crucial for adequate body cells building and maintenance, while fiber is necessary for bowel movement and easy digestion of food.

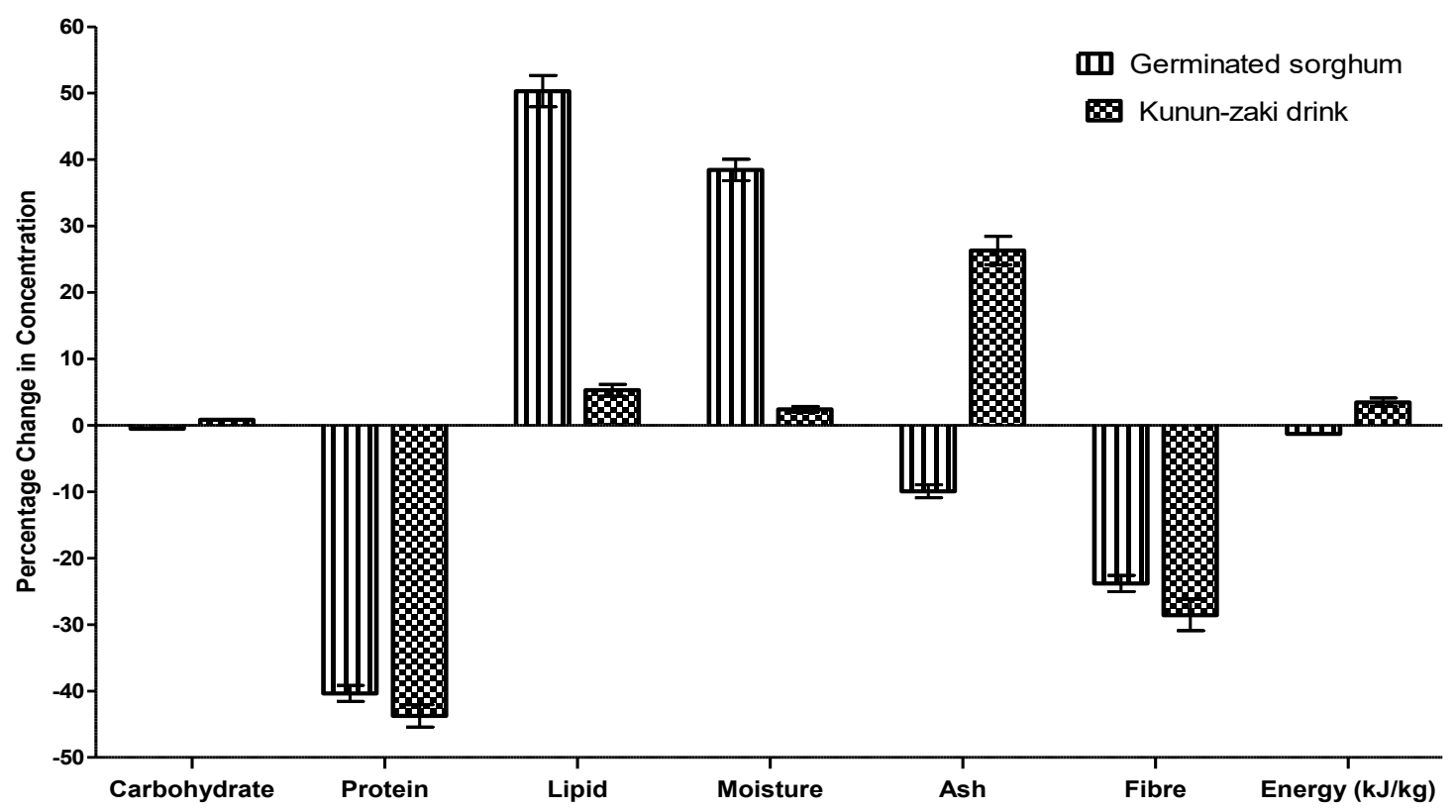

Figure 2: Percentage changes in the proximate compositions of germinated sorghum and Kunu-zaki drink in comparison with those of the raw sorghum sample.

\subsection{Changes in mineral composition of germinated sorghum and kunu-zaki.}

The mineral composition of the samples studied is shown in Table 2. Potassium $(\mathrm{K})$ and sodium $(\mathrm{Na})$ are major macro-elements, while phosphorus $(\mathrm{P})$ is the highest micro-element present in the samples. There were significantly $(\mathrm{p}<0.05)$ more minerals in the adjunct (raw sweet potato) than the main ingredient (sorghum) in kunu-zaki production. Sweet potato is one of the vegetable crops that is largely neglected but has been reported to contain essential mineral nutrients, vitamins and functional phytochemicals [19]. The presence of these essential minerals in potato may have contributed to the significantly $(\mathrm{p}<0.05)$ higher levels of these minerals, including zinc $(\mathrm{Zn})$ and iron (Fe), in the kunu-zaki than the germinated sorghum; when compared with their baseline values 
in the raw sorghum (Figure 3). Furthermore, a combination of the two processing techniques of germination and fermentation in kunu-zaki production, unlike in the germinated sample only, may have aided in the significantly $(\mathrm{p}<0.05)$ high increase in the mineral content of kunu-zaki than in germinated sorghum. Germination and fermentation are traditional methods used in the processing of cereals and legumes, which have recently been found and documented to increase their palatability and nutritional value via increased activity of endogenous enzymes which breakdown large macromolecules to smaller units such as starch to sugars, and also degrade anti-nutrients, thereby liberating chelated minerals and increasing their availability $[7,8]$.

Table 2: Mineral composition $(\mathrm{mg} / 100 \mathrm{~g})$ of raw sorghum, raw potato, germinated sorghum and kunu-zaki.

\begin{tabular}{|l|l|l|l|l|}
\hline Mineral & Raw sorghum & Raw potato & $\begin{array}{l}\text { Germinated } \\
\text { sorghum }\end{array}$ & Kunu-zaki \\
\hline Macrominerals \\
\hline Sodium & $446.50 \pm 30.30^{\mathrm{a}}$ & $484.50 \pm 22.11^{\mathrm{ac}}$ & $522.50 \pm 16.53^{\mathrm{bc}}$ & $541.50 \pm 23.85^{\mathrm{b}}$ \\
\hline Potassium & $750.50 \pm 61.11^{\mathrm{a}}$ & $798.10 \pm 50.72^{\mathrm{a}}$ & $722.00 \pm 48.21^{\mathrm{a}}$ & $769.50 \pm 50.56^{\mathrm{a}}$ \\
\hline Magnesium & $2.55 \pm 0.06^{\mathrm{ac}}$ & $2.80 \pm 0.09^{\mathrm{b}}$ & $2.45 \pm 0.04^{\mathrm{a}}$ & $2.65 \pm 0.09^{\mathrm{bc}^{\mathrm{c}}}$ \\
\hline Calcium & $1.70 \pm 0.08^{\mathrm{a}}$ & $1.95 \pm 0.03^{\mathrm{bc}}$ & $1.80 \pm 0.05^{\mathrm{ac}}$ & $2.05 \pm 0.08^{\mathrm{b}}$ \\
\hline Microminerals \\
\hline Phosphorus & $66.60 \pm 1.18^{\mathrm{a}}$ & $69.70 \pm 2.02^{\mathrm{ab}}$ & $71.74 \pm 1.71^{\mathrm{b}}$ & $70.72 \pm 1.38^{\mathrm{ab}}$ \\
\hline Iron & $1.85 \pm 0.03^{\mathrm{a}}$ & $2.15 \pm 0.07^{\mathrm{b}}$ & $1.95 \pm 0.03^{\mathrm{a}}$ & $2.25 \pm 0.05^{\mathrm{b}}$ \\
\hline Zinc & $3.35 \pm 0.11^{\mathrm{a}}$ & $3.70 \pm 0.14^{\mathrm{bc}}$ & $3.45 \pm 0.09^{\mathrm{ac}}$ & $3.80 \pm 0.10^{\mathrm{b}}$ \\
\hline
\end{tabular}

Values are mean \pm standard deviations of triplicate determinations. Values with similar superscripts per row are not significant $(\mathrm{p}<0.05)$ different.

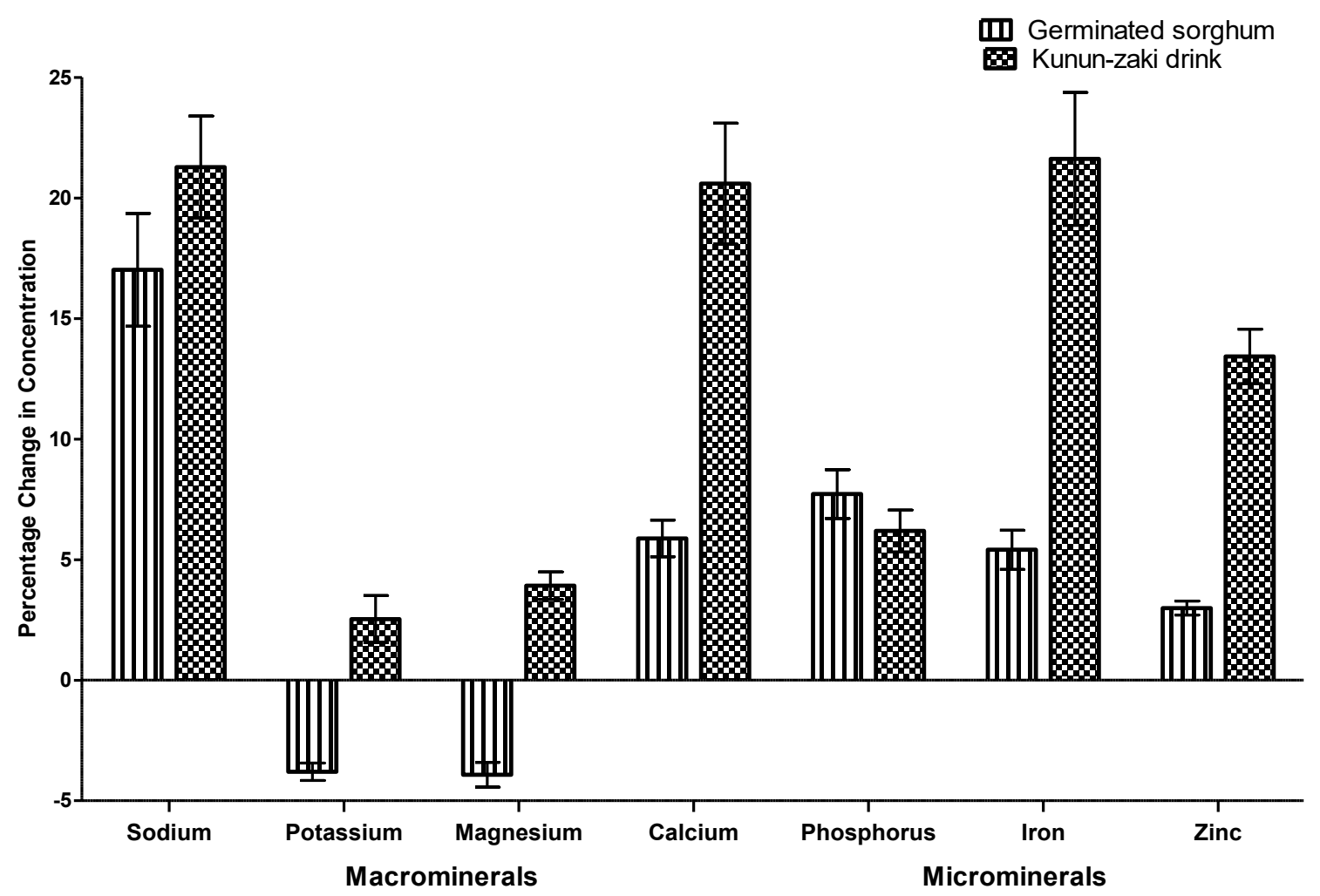

Figure 3: Percentage changes in the mineral compositions of germinated sorghum and kunu-zaki drink in comparison with those of the raw sorghum sample. 


\subsection{Changes in phytochemical composition of germinated sorghum and kunu-zaki.}

As earlier inferred, anti-nutrients appreciably reduce palatability and nutritional value of plantbased foods that contain them. Although, most anti-nutrients are phytochemicals, but not all phytochemicals are anti-nutrients. Certain phytochemicals such as flavonoids are functional compounds that may act as antioxidants. Others like alkaloids and saponins are major sources of plant-based drugs, while oxalates and phytates are majorly described as anti-nutrients. The contents of these anti-nutrients in particular, and phytochemicals in general, have been reported to be significantly reduced by traditional methods of food processing such as soaking, boiling, fermentation, germination, dehydration, and cooking [7,8].

Table 3: Phytochemical composition (\%) of raw sorghum, raw potato, germinated sorghum and kunu-zaki.

\begin{tabular}{|l|l|l|l|l|}
\hline Phytochemical & Raw sorghum & Raw potato & $\begin{array}{l}\text { Germinated } \\
\text { sorghum }\end{array}$ & Kunu-zaki \\
\hline Flavonoid & $4.50 \pm 0.08^{\mathrm{a}}$ & $3.00 \pm 0.04^{\mathrm{b}}$ & $4.50 \pm 0.11^{\mathrm{a}}$ & $4.05 \pm 0.06^{\mathrm{c}}$ \\
\hline Phenols & $12.26 \pm 1.03^{\mathrm{a}}$ & $16.13 \pm 1.00^{\mathrm{b}}$ & $5.63 \pm 0.80^{\mathrm{c}}$ & $6.89 \pm 1.07^{\mathrm{c}}$ \\
\hline Alkaloid & $5.00 \pm 0.18^{\mathrm{a}}$ & $3.00 \pm 0.05^{\mathrm{b}}$ & $4.50 \pm 0.10^{\mathrm{c}}$ & $6.50 \pm 0.11^{\mathrm{d}}$ \\
\hline Saponin & $1.50 \pm 0.05^{\mathrm{a}}$ & $1.56 \pm 0.01^{\mathrm{a}}$ & $1.50 \pm 0.01^{\mathrm{a}}$ & $0.56 \pm 0.00^{\mathrm{b}}$ \\
\hline Tannin & $1.76 \pm 0.08^{\mathrm{a}}$ & $1.58 \pm 0.03^{\mathrm{b}}$ & $1.60 \pm 0.02^{\mathrm{b}}$ & $1.23 \pm 0.03^{\mathrm{c}}$ \\
\hline Oxalate & $3.00 \pm 0.10^{\mathrm{a}}$ & $4.60 \pm 0.08^{\mathrm{b}}$ & $2.40 \pm 0.01^{\mathrm{c}}$ & $2.00 \pm 0.02^{\mathrm{d}}$ \\
\hline $\begin{array}{l}\text { Cyanogenic } \\
\text { glycoside }\end{array}$ & $2.72 \pm 0.12^{\mathrm{ab}}$ & $3.09 \pm 0.11^{\mathrm{b}}$ & $2.40 \pm 0.03^{\mathrm{c}}$ & $2.93 \pm 0.06^{\mathrm{b}}$ \\
\hline $\begin{array}{l}\text { Phytate } \\
\text { (mg/100g) }\end{array}$ & $621.95 \pm 3.18^{\mathrm{a}}$ & $1479.08 \pm 5.81^{\mathrm{b}}$ & $553.79 \pm 5.37^{\mathrm{c}}$ & $247.07 \pm 2.13^{\mathrm{d}}$ \\
\hline
\end{tabular}

Values are mean \pm standard deviations of triplicate determinations. Values with similar superscripts per row are not significantly $(\mathrm{p}<0.05)$ different.

The results of the present study (Table 3$)$ show that there were significantly $(p<0.05)$ more array of phytochemicals in the sweet potato tuber than in the sorghum cereal. This observation corroborates the report that sweet potato is an excellent source of anti-oxidative polyphenolics, among them anthocyanins and phenolic acids; but that oxalic acid poses a problem when using sweet potato as food [20]. The food content of oxalate, along with other anti-nutrients are usually eliminated or drastically reduced during processing. This may explain the significant $(p<0.05)$ reductions in the concentrations of almost all the phytochemicals in both the germinated sorghum and kunu-zaki. The reductions being more pronounced in the kunu-zaki than the germinated sorghum (Figure 4); notwithstanding the addition of the raw sweet potato paste. For instance, phytate and oxalate were reduced by $10.96 \%$ and $20.00 \%$ in germinated sorghum, and $60.27 \%$ and $33.33 \%$ in kunu-zaki, respectively (Figure 4). This may indicate a synergism between germination and fermentation in the activation of anti-nutrient-degrading enzymes. These process combinations may offer more practical advantage over germination or fermentation alone, since it was reported that long germination periods are needed to improve mineral bioavailability through germination of sorghum to enhance phytate-degrading enzyme activity [7]. The reason for the significant increases in the flavonoid and alkaloid contents of the kunu-zaki, which are apparently beneficial because of their functional potentials may not easily be deduced. However, they may have increased due to the addition of sweet potato paste, but because other phytochemicals did not, the reason may not be foolproof, and thus calls for more research for further clarification. 


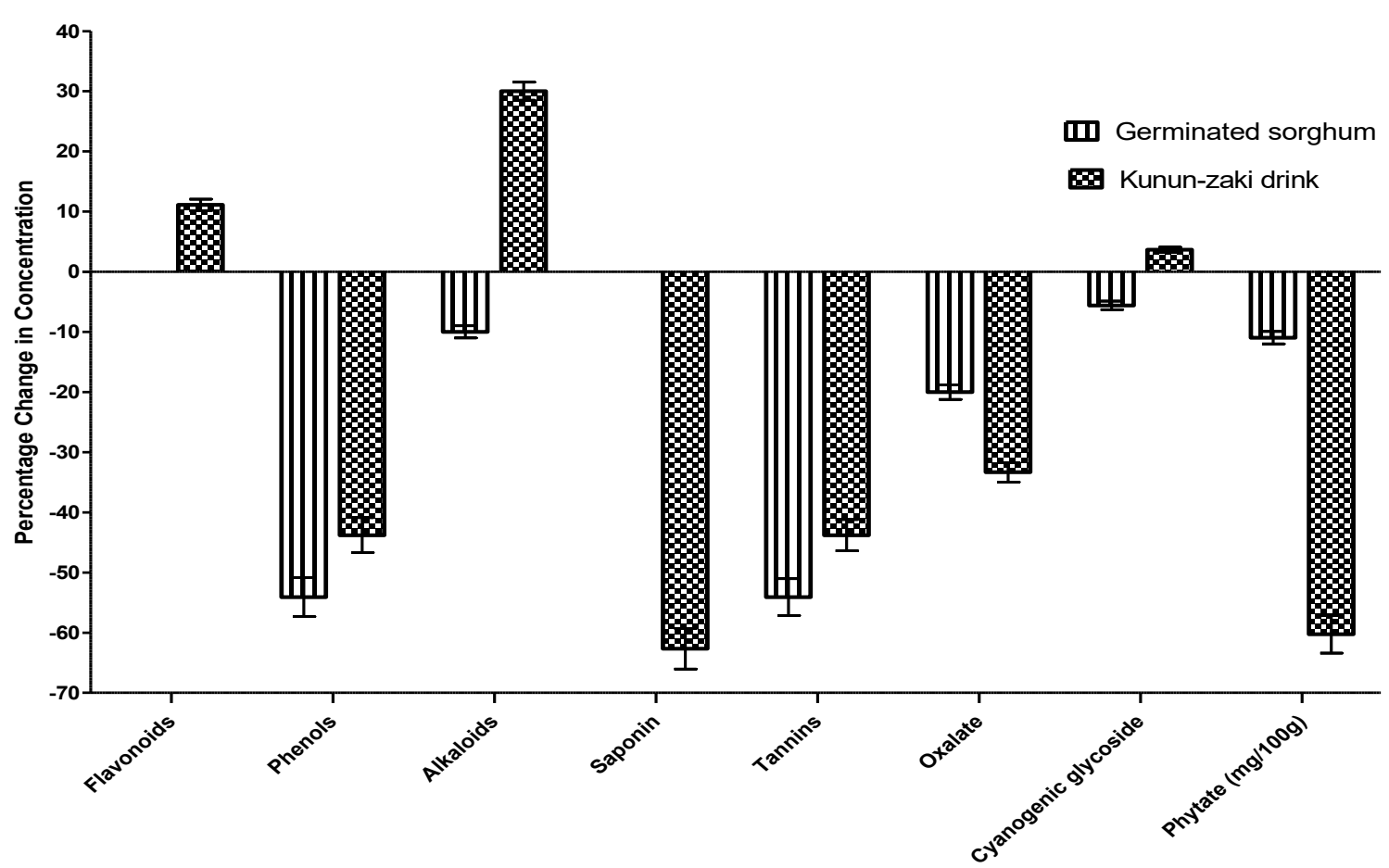

Figure 4: Percentage change in the phytochemical compositions of fermented sorghum and kunuzaki drink in comparison with those of the raw sorghum sample.

\subsection{Changes in computed mineral ratios, and $\mathrm{Fe}, \mathrm{Zn}$, $\mathrm{Ca}$ and Phytate molar ratios of germinated sorghum and kunu-zaki.}

The computed mineral ratio of the samples are shown in Table 4 . The $\mathrm{Ca} / \mathrm{P}$ ratio was generally lower than 0.5 which was reported to be the minimum ratio required for favourable absorption of $\mathrm{Ca}$ in the intestine [8]. Calcium is an important constituent of body fluids and is required along with phosphorus for bone formation. Thus, the levels of $\mathrm{Ca} / \mathrm{P}$ ratios in both the raw and processed samples indicated that consumption of kunu-zaki as the sole sources of $\mathrm{Ca}$ and $\mathrm{P}$ may not enhance strong bone development and maintenance, especially in children, since absorption under this condition would not be adequate. The $\mathrm{Na} / \mathrm{K}$ ratios, were greater than 0.60 , a value reported not to favour enhancement of high blood pressure in man [17], thus adequate for maintenance of homeostatic localization of $\mathrm{Na}$ and $\mathrm{K}$ in the extracellular and intracellular compartments of the body, respectively. Interestingly, the production of kunu-zaki significantly $(p<0.05)$ increased this ratio in comparison with those of the raw samples. On the other hand, the $\mathrm{Ca} / \mathrm{Mg}$ ratio which ranged from $0.67 \pm 0.05$ (raw sorghum) to $0.77 \pm 0.06$ (kunu-zaki) were lower than the recommended value of 1.0 [17]. Similarly, the calculated milliequivalent ratios of $[\mathrm{K} /(\mathrm{Ca}+\mathrm{Mg})]$ were all less than 2.2 as reported by [17]. The results buttress the reported low mineral nutrient content of sorghum and kunu-zaki, and calls for further fortification of kunu-zaki with other mineral nutrient rich sources. Table 4 also shows the $\mathrm{Fe}, \mathrm{Zn}, \mathrm{Ca}$ and phytate (Phy) molar ratios of the samples. Phytate/Fe and phytate/Zn molar ratios are associated with $\mathrm{Fe}$ and $\mathrm{Zn}$ bioavailability. The results show that the phytate/Fe molar ratios ranged from $9.35 \pm 0.05$ in kunu-zaki to $31.06 \pm 0.06$ in raw potato, while the phytate/Zn molar ratio ranged from $6.45 \pm 0.05$ in kunu-zaki to $20.70 \pm 0.08$ in raw potato. It has been reported that ideal phytate/Fe molar ratio should be lower than 14, which is the critical value above which Fe bioavailability is strongly impaired [21]. Similarly, it was showed that foods with phytate/Zn molar ratios less than 10 encourage the bioavailability of $\mathrm{Zn}$, but problems may arise when the values are greater than 15 [22]. Our results proved that the combined processes of germination and fermentation of sorghum into kunu-zaki significantly $(p<0.05)$ reduced the phytate/Fe and phytate/Zn molar ratios of sorghum to values $(9.35 \pm 0.05$ and $6.45 \pm 0.05$, respectively) within the acceptable limit. The above observations re-enforce previous results that showed that the bioavailability of $\mathrm{Zn}$ and $\mathrm{Fe}$ in cereals and legumes are low but are generally improved by various processing techniques $[7,8,23]$. 
Table 4: Computed mineral ratios, and $\mathrm{Fe}, \mathrm{Zn}, \mathrm{Ca}$ and Phytate molar ratios of raw sorghum, raw potato, germinated sorghum and kunu-zaki.

\begin{tabular}{|l|l|l|l|l|}
\hline Ratio & Raw sorghum & Raw potato & $\begin{array}{l}\text { Germinated } \\
\text { sorghum }\end{array}$ & Kunu-zaki \\
\hline Mineral ratios & $0.03 \pm 0.00^{\mathrm{a}}$ & $0.03 \pm 0.00^{\mathrm{a}}$ & $0.03 \pm 0.00^{\mathrm{a}}$ & $0.03 \pm 0.00^{\mathrm{a}}$ \\
\hline $\mathrm{Ca} / \mathrm{P}$ & $0.60 \pm 0.02^{\mathrm{a}}$ & $0.61 \pm 0.04^{\mathrm{a}}$ & $0.72 \pm 0.02^{\mathrm{b}}$ & $0.70 \pm 0.01^{\mathrm{b}}$ \\
\hline $\mathrm{Na} / \mathrm{K}$ & $0.67 \pm 0.05^{\mathrm{a}}$ & $0.70 \pm 0.03^{\mathrm{a}}$ & $0.74 \pm 0.08^{\mathrm{a}}$ & $0.77 \pm 0.06^{\mathrm{a}}$ \\
\hline $\mathrm{Ca} / \mathrm{Mg}$ & $8.83 \pm 0.12^{\mathrm{a}}$ & $8.40 \pm 0.09^{\mathrm{bc}}$ & $8.49 \pm 0.10^{\mathrm{b}}$ & $8.19 \pm 0.08^{\mathrm{c}}$ \\
\hline$[\mathrm{K} /(\mathrm{Ca}+\mathrm{Mg})]^{\mathrm{a}}$ & \multicolumn{5}{|l|}{} \\
\hline Molar ratios & $28.56 \pm 0.09^{\mathrm{a}}$ & $31.06 \pm 0.06^{\mathrm{b}}$ & $24.00 \pm 0.10^{\mathrm{c}}$ & $9.35 \pm 0.05^{\mathrm{d}}$ \\
\hline$[\mathrm{Phy}]:[\mathrm{Fe}]$ & $18.47 \pm 0.07^{\mathrm{a}}$ & $20.70 \pm 0.08^{\mathrm{b}}$ & $15.83 \pm 0.04^{\mathrm{c}}$ & $6.45 \pm 0.05^{\mathrm{d}}$ \\
\hline$[\mathrm{Phy}]:[\mathrm{Zn}]$ & $0.05 \pm 0.01^{\mathrm{a}}$ & $0.04 \pm 0.01^{\mathrm{a}}$ & $0.05 \pm 0.02^{\mathrm{a}}$ & $0.14 \pm 0.03^{\mathrm{b}}$ \\
\hline$[\mathrm{Ca}]:[\mathrm{Phy}]$ & $0.78 \pm 0.06^{\mathrm{a}}$ & $1.01 \pm 0.04^{\mathrm{b}}$ & $0.71 \pm 0.09^{\mathrm{a}}$ & $0.34 \pm 0.01^{\mathrm{c}}$ \\
\hline$[\mathrm{Ca}][\mathrm{Phy}] /[\mathrm{Zn}]$
\end{tabular}

${ }^{a}$ Milliequivalent ratio. Values are mean \pm standard deviations of triplicate determinations. Values with similar superscripts per row are not significantly $(p<0.05)$ different.

Meanwhile, [24] suggested that the solubility of phytate and the proportion of $\mathrm{Zn}$ bound in a mineral complex with phytate in the intestine depend on the levels of Ca. Based on this assertion, phytate precipitation is not complete until dietary $\mathrm{Ca}$ /phytate molar ratio gets to a value of approximately $6: 1$. Thus, when $\mathrm{Ca}$ /phytate molar ratio is less than $6: 1$, phytate precipitation is incomplete and some of the dietary $\mathrm{Zn}$ remain in solution. By extension, the proportion remaining in solution increases with decreasing $\mathrm{Ca}$ /phytate molar ratio [17]. The $\mathrm{Ca}$ /phytate molar ratios of our samples are all below the critical ratio, indicating that their Ca content was sufficiently low to promote phytate-induced decreases in $\mathrm{Zn}$ bioavailability.

[25] suggested that $[\mathrm{Ca}][\mathrm{Phy}] /[\mathrm{Zn}]$ ratio may be a better predictor of $\mathrm{Zn}$ bioavailability than phytate $/ \mathrm{Zn}$ and $\mathrm{Ca} /$ phytate; noting that if the value was greater than $0.50 \mathrm{~mol} / \mathrm{kg}$, there would be interferences with the availability of $\mathrm{Zn}$. In our results, the $[\mathrm{Ca}][\mathrm{Phy}] /[\mathrm{Zn}]$ values for raw sorghum, raw potato and germinated sorghum were higher than the proposed cut-off point of $0.50 \mathrm{~mol} / \mathrm{kg}$; indicating that $\mathrm{Zn}$ would not be adequately available in the samples. However, the combined processes of germination and fermentation caused a significant $(p<0.05)$ reduction in the $[\mathrm{Ca}][\mathrm{Phy}] /[\mathrm{Zn}]$ values of the raw and germinated sorghum to obtain a value of $0.34 \pm 0.01$ for kunuzaki, which was lower than the recommended $0.5 \mathrm{~mol} / \mathrm{kg}$. The results underpin the synergistic advantage of combining germination and fermentation processes in kunu-zaki production in improving the nutritional quality of the beverage.

\subsection{Conclusion}

In conclusion, this study showed that kunu-zaki is a good source of carbohydrate, energy, minerals and functional phytochemicals, but requires fortification or intake with protein and fiber rich foods. Furthermore, the beverage showed potentially high Fe and $\mathrm{Zn}$ bioavailability; notwithstanding the poor bioavailability of these mineral in both raw and germinated sorghum. These were shown to have been significantly improved by the combined processes of germination and fermentation through significant reductions in anti-nutrient contents with concomitant liberation of the essential minerals. 


\section{References}

[1] C.O. Ibegbulem, P.C. Chikezie, Biochemical indices and sensory scores of kunu-zaki beverages produced from sprouted and unsprouted guinea corn and their correlations. Am. J. Food Technol. 2014. Http://dx.doi.org/3923/ajft.2014.

[2] J.A. Ayo, O.G. Onuoha, D.S. Ikuomola, Y.O. Esan, V.A. Ayo, I.G. Oigiangbe, Nutrition Evaluation of Millet-beniseed Composite Based Kunu-zaki. Pak. J. Nutr. 9(2010) 1034-1038.

[3] T. Gaffa, Improving Traditional Kunu Production and its Storage Stability. Ph.D Thesis. Biological Science Programme, Abubarkar Tafawa Balewa University of Bauchi, Nigeria, 2000.

[4] O. Akoma, E.A. Jiya, D.D. Akumka, E. Mshelia, Influence of Malting on the Nutritional Characteristics of Kunu-zaki. Afri. J. Biotech. 5(2006) 996-1000.

[5] S.O. Oluwajoba, F.A. Akinyosoye, O.V. Oyetayo, Comparative Sensory and Proximate Evaluation of Spontaneously fermenting Kunu-zaki made from germinated and ungerminated composite cereal grains. Food Sci. Nutr. 1(2013) 336-349.

[6] T.S. Kahlon, Evaluating healthful properties of cereals and cereal fractions by their bile-acidbinding potential. Cereal Foods World 54 (2009)118-121.

[7] A.M.R. Afify, H.S. El-Beltagi, S.M. Abd El-Salam, A.A. Omran, Bioavailability of Iron, Zinc, Phytate and Phytase Activity during Soaking and Germination of white Sorghum Varieties. PLoS ONE 6(2011) e255512. Http://dx.doi.org/10.1371/journal.pone.0025512.

[8] C.U. Igwe, C.O. Ibegbulem, L.A. Nwaogu, C.O. Ujowundu, G.N. Okwu, Calcium, Zinc and Phytate Interrelationships in Four Lesser-Known African Seeds Processed into Food Condiments. J. Adv. Chem. 4(2013) 288-294.

[9] F.T. Akinhanmi, A.L. Arogundade, O.M. Tiamiyi, E. Oloruntoba, Protein fractions of legumes and cereals consumed in Nigeria. Int. J. Agric. Sci. Sci. Environ. Technol. 7(2008) 54-62.

[10] A.O.A.C. Official Methods of Analysis of the Association of Analytical Chemists, Washington D.C. 1990.

[11] J.E. Stewart, Use of Atwater factors in USDA's Nutrient Data Bank. Talk at the Nutrient Data Bank Conference, USA. 1992.

[12] D. Pearson, The Chemical Analysis of Food. Churchill Livingstone, Edinburgh. 1976.

[13] I.B. Harborne, Phytochemical methods: A guide to modern techniques of plant analysis. $2^{\text {nd }}$ ed. Chapman and Hall, New York. 1973.

[14] G.E. Trease, W.C. Evans, Pharmacognosy. $13^{\text {th }}$ ed. Bacilliere Tinall Ltd, London. 1989.

[15] A. Aberoumand, S.S. Deokule, Comparison of phenolic compounds of some edible plants of Iran and India. Pak. J. Nutr. 7(2008) 582-585.

[16] A. Mohammed, P.J. Perera, Y.S. Hafez, New chromophore for phytic acid determination. Cereal Chem. 63(1986) 475-478.

[17] E.I. Adeyeye, O.T. Orisakeye, M.A. Oyarekua, Composition, Mineral Safety Index, Calcium, Zinc and Phytate Interrelationships in Four Fast-Foods Consumed in Nigeria. Bull. Chem. Soc. Ethiop. 26(2012) 43-54.

[18] N.A. Amusa, O.A. Ashaye, Effect of Processing on Nutritional, Microbiological and Sensory Properties of Kunu-zaki (A Sorghum based non-alcoholic Beverage) widely consumed in Nigeria. Pak. J. Nutr. 8(2009): 288-292.

[19] J.A. Woolfe, Sweet potato. An Untapped Food Resource, Cambridge University Press, Cambridge, U.K. 1992. 
[20] K. Ishiguro, J. Toyama, S. Islam, M. Yoshimoto, T. Kumagai, Y. Kai, O. Yamakawa, "Suioh, A New Sweet potato Cultivar for Utilization in Vegetable Greens," Acta. Hortic. 637 (2004) 339-345.

[21] A.P.P. Kayode, Diversity, users' perception and food processing of sorghum: Implications for dietary iron and zinc supply. Ph.D. thesis Wageningen University, Wageningen, The Netherlands. 2006.

[22] D. Oberleas, B.F. Harland, Phytate content of foods: Effect on dietary zinc bioavailability. J. Am. Diet Assoc. 79(1981) 433-436

[23] E.I. Adeyeye, L.A. Arogundade, E.T. Akintayo, O.A. Aisida, P.A. Alao, Calcium, zinc and phytate interrelationships in some foods of major consumption in Nigeria. Food Chem. 71(2000) 435-441.

[24] A. Wise, Dietary factors determining the biological activities of phytate. Nutr. Abstr. Rev./Rev. Clin. Nutr. 53 (1983) 791-806.

[25] N.T. Davis, S. Warrington, The phytic acid mineral, trace element, protein and moisture content of UK Asian immigrant foods. Hum. Nutr. Appl. Nutr. 40A (1986) 49-59. 